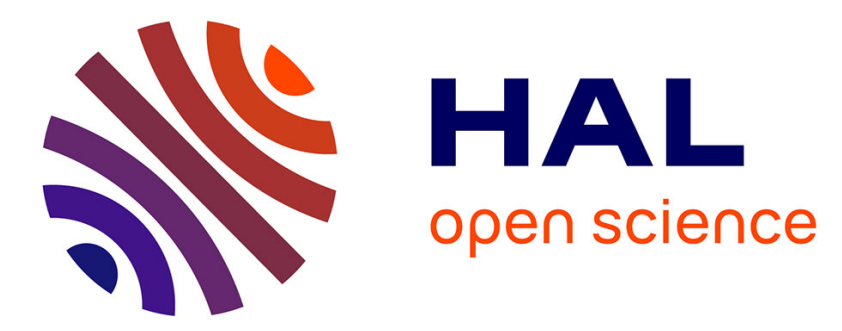

\title{
Easy installation of 1,2,3-triazoles or iodo-1,2,3-triazoles onto indole-fused oxazinones via CuAAC-based MCR in the presence of 18-crown-6
}

A Mayooufi, M Romdhani-Younes, Y Carcenac, Jérôme Thibonnet

\section{- To cite this version:}

A Mayooufi, M Romdhani-Younes, Y Carcenac, Jérôme Thibonnet. Easy installation of 1,2,3-triazoles or iodo-1,2,3-triazoles onto indole-fused oxazinones via CuAAC-based MCR in the presence of 18crown-6. Synthetic Communications, inPress, 10.1080/00397911.2019.1611857 . hal-02172442

\author{
HAL Id: hal-02172442 \\ https://hal.science/hal-02172442
}

Submitted on 3 Jul 2019

HAL is a multi-disciplinary open access archive for the deposit and dissemination of scientific research documents, whether they are published or not. The documents may come from teaching and research institutions in France or abroad, or from public or private research centers.
L'archive ouverte pluridisciplinaire HAL, est destinée au dépôt et à la diffusion de documents scientifiques de niveau recherche, publiés ou non, émanant des établissements d'enseignement et de recherche français ou étrangers, des laboratoires publics ou privés. 


\section{Easy installation of 1,2,3-triazoles or iodo-1,2,3-triazoles onto indole-fused oxazinones via CuAAC-based MCR in the presence of 18-crown-6}

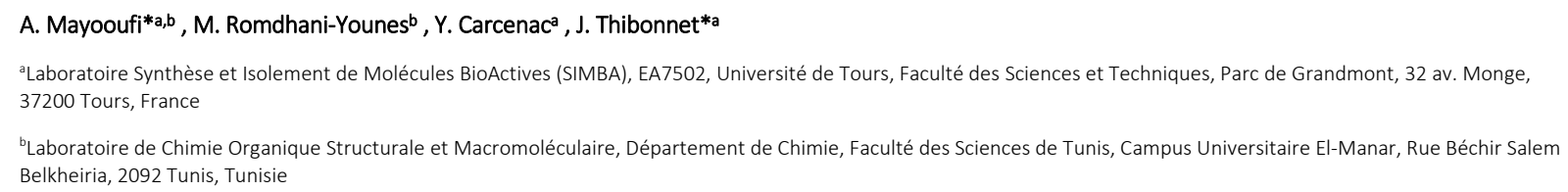

'Laboratoire de Chimie Organique Structurale et Macromoléculaire, Département de Chimie, Faculté des Sciences de Tunis, Campus Universitaire El-Manar, Rue Béchir Salem Belkheiria, 2092 Tunis, Tunisie

\section{Abstract}

An efficient protocol was developed to prepare indole-fused oxazinones using silver nitrate. The latter substrates were subjected to multicomponent reactions in the presence of 18-crown6, which afforded diverse new heterocycles based on an indole-fused oxazinone-1,2,3-triazole scaffold.
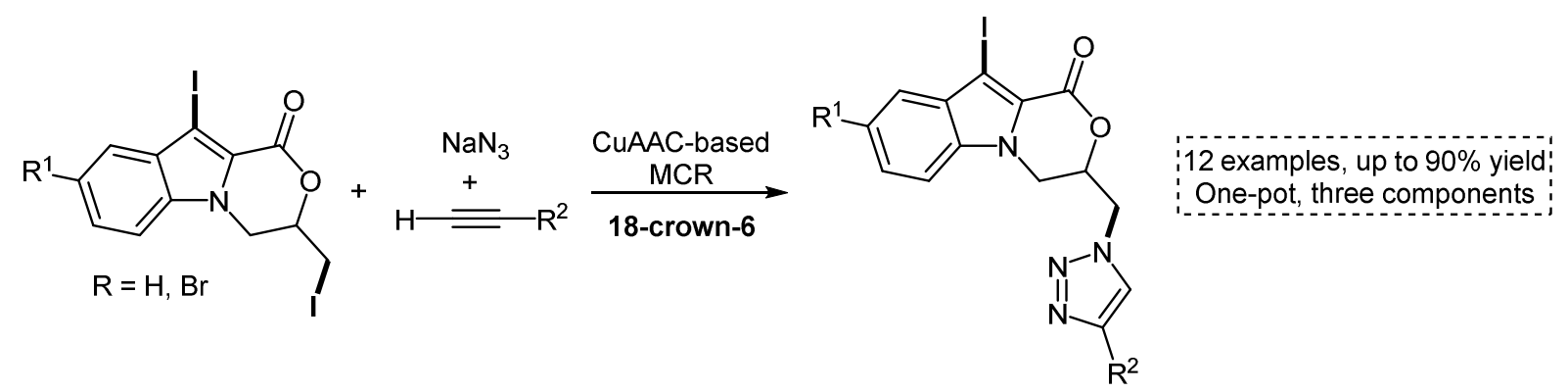

Key words

click chemistry, iodolactonization, multicomponent reactions, azides, iodo-triazoles

\section{Introduction}

Polycyclic indole scaffolds constitute the structural core of numerous important classes of molecules that display an extensive range of biological and pharmacological properties. ${ }^{[1]}$ For example HKI 0231A and HKI 0231B have shown the ability to inhibit $3 \alpha$-hydroxysteroid dehydrogenase, which is a key enzyme in the inflammatory process. ${ }^{[2]}$ More complex polycyclic indole alkaloids, such as vincristine and vinblastine (antitumor agents), ${ }^{[3]}$ have been widely investigated. ${ }^{[4]}$ Triazole-bearing indoles (Figure 1) have also shown wide-ranging biological activities, such as compound $\mathbf{A}$ (anti-adipogenic and anti-dyslipidemic activity), ${ }^{[5]}$ molecule $\mathbf{B}$ (selective inhibitors and inducers of bacterial biofilms), ${ }^{[6]}$ compound $\mathbf{C}$ (antimicrobial activity), ${ }^{[7]}$ and compound $\mathbf{D}$ (antifungal agent). ${ }^{[8]}$ In addition, indole-fused oxazinone derivatives are present in a large number of bioactive compounds and some representative members of this family are also depicted in Figure 1. For example, compound $\mathbf{E},{ }^{[9]}$ compound $\mathbf{F},{ }^{[10]}$ and compound $\mathbf{G},{ }^{[11]}$ show anticancer properties. Etodolac $\mathbf{H}$ is used for 
the treatment of arthritis, ${ }^{[12]}$ and oxazinoindolones I showed anti-inflammatory activity. ${ }^{[13]}$ The aforementioned findings (Figure 1) gained our attention because of their great importance in biological sciences, and because these structures have rarely been described in the literature.<smiles>CN(Cc1cn(Cc2cccc(F)c2F)nn1)Cc1cn(C)c2ccccc12</smiles><smiles>CC(C)(C)c1ccc(C(=O)NCCn2cc(Cc3c[nH]c4ccccc34)nn2)cc1</smiles>

indole-linker-triazoles
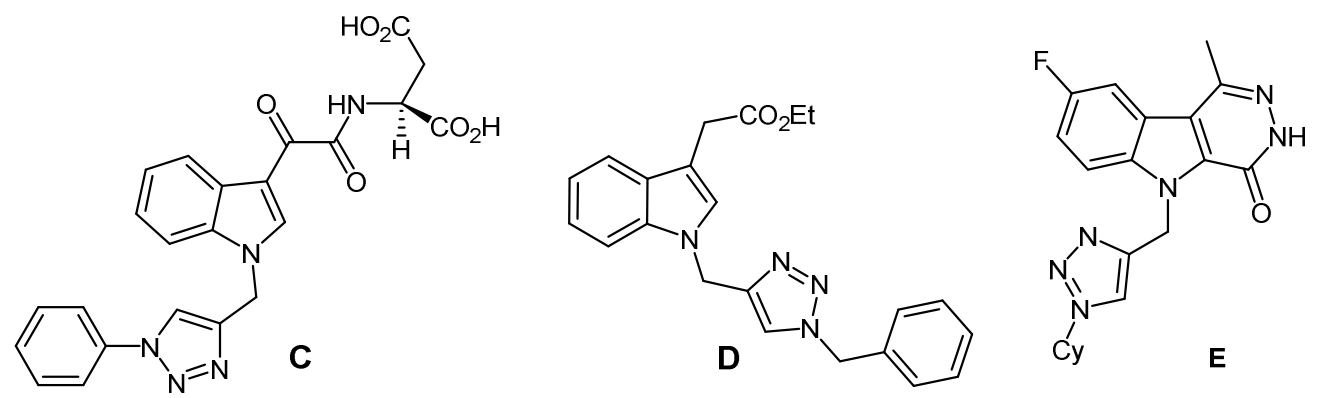<smiles>Cc1c(C(=O)c2ccc3ccccc3c2)c2cccc3c2n1[C@@H](CN1CCOCC1)CO3</smiles>
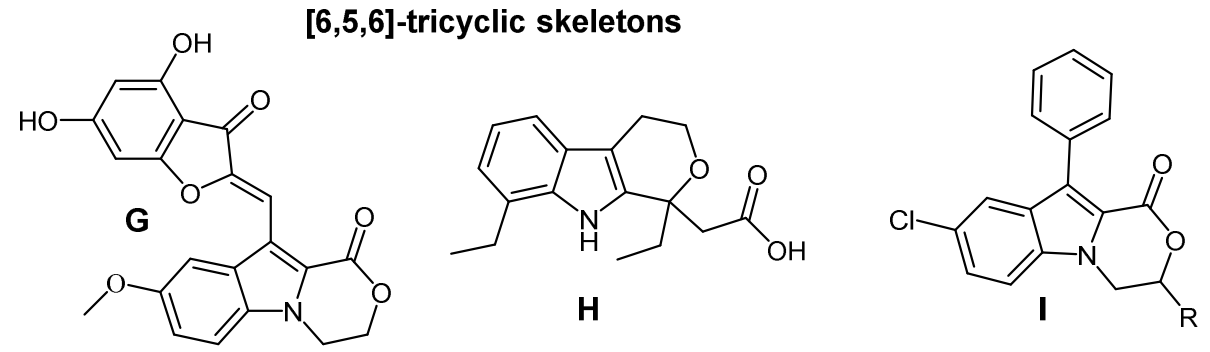

Figure 1. Selected biologically active indole-fused oxazinones and indoles incorporating the 1,2,3-triazole moiety.

We envisioned that combining a triazole moiety with the indole fused oxazinones scaffold may lead to potentially bioactive molecules. In the present work, we describe an easy way to install 1,2,3-triazole and iodo-triazole moieties onto indole-fused oxazinones through an efficient CuAAC-based multicomponent reaction in the presence of 18-crown-6 (Figure 2). 


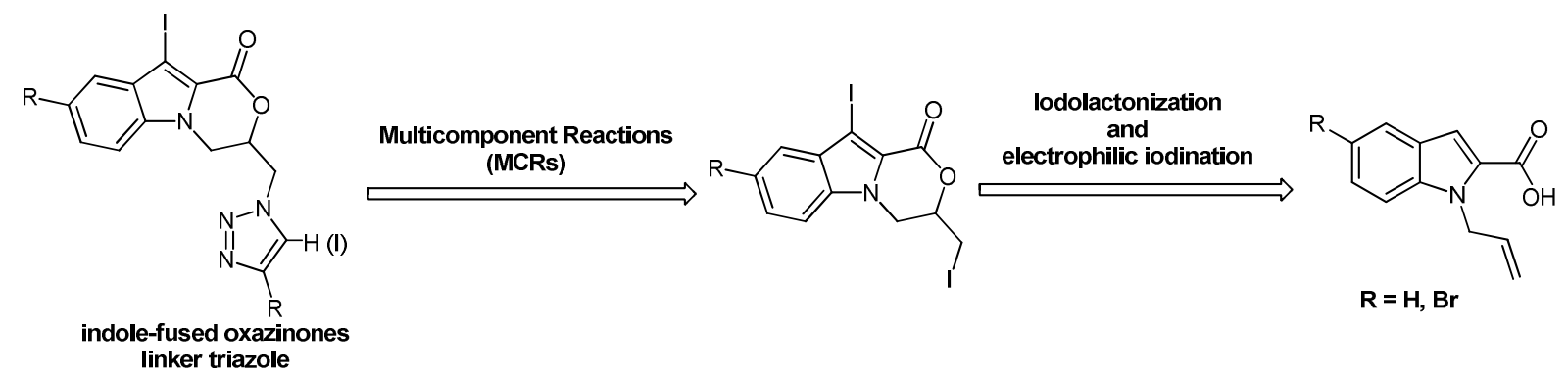

Figure 2. Retrosynthetic strategy for the sequential synthesis of indole-fused oxazinones incorporating the 1,2,3-triazole moiety.

\section{Results and discussion}

To achieve our goals, the appropriate cyclization precursors 3a-b were obtained in two steps starting from ester indoles 1a-b (Scheme 1). After $N$-alkylation of the latter with allyl bromide, the resulting indole was saponified to $\mathbf{3 a - b}$ in good yields.
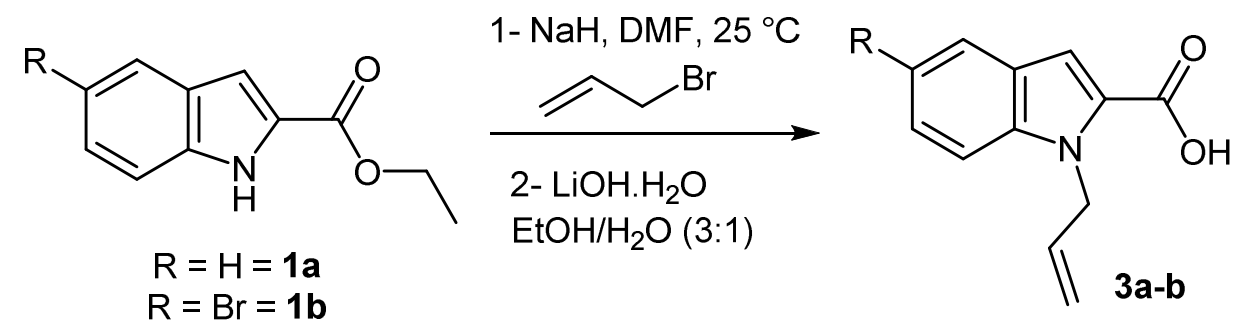

Scheme 1. Preparation of acids 3a-b.

For the iodocyclization reaction, other workers ${ }^{14}$ reported that the use of $\mathrm{I}_{2}$ and $\mathrm{NaHCO}_{3}$ at 70 ${ }^{\circ} \mathrm{C}$ afforded the products $\mathbf{4 a}$ in $84 \%$ yield while using NIS and lutidine gave the desired compound 4a in $81 \%$ yield (Table 1, entries 1 and 2). For our part, we wished to re-examine this iodocyclization reaction. Firstly, we tested the efficacy of different sources of electrophilic iodine, such as ICl and NIS instead of $\mathrm{I}_{2}$ without changing other factors (Table 1, entries 3 and 4), but we observed a decrease in the yield of the desired product 4a. We then evaluated the effect of different bases on the iodine-mediated electrophilic cyclization of $\mathbf{3 a}$ (Table 1, entries 5-8). The results showed that sodium hydride was the most effective base at room temperature (Table 1, entry 8). To optimize the reaction conditions, we tested the addition of $\mathrm{AgNO}_{3}$, and this effectively improved the conversion to reach $99 \%$ of the desired product (Table 1, entry 9). An increase in the quantity of the latter additive from 0.5 to 1 equiv reduced the reaction time from $2 \mathrm{~h}$ to $30 \mathrm{~min}$, but the yield was not improved (Table 1, entries 10 and 11). Compound $\mathbf{4 b}$ was also obtained in good yield (95\%) under the same conditions. This protocol displayed 
higher yields and lower reaction times than that previously reported by Joseph and coworkers. $^{[14]}$

Table 1. Optimization of Iodolactonization.

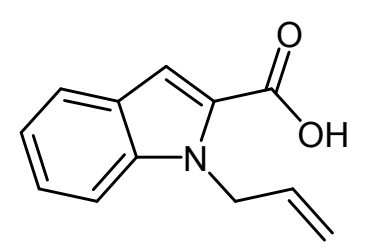

$3 a$

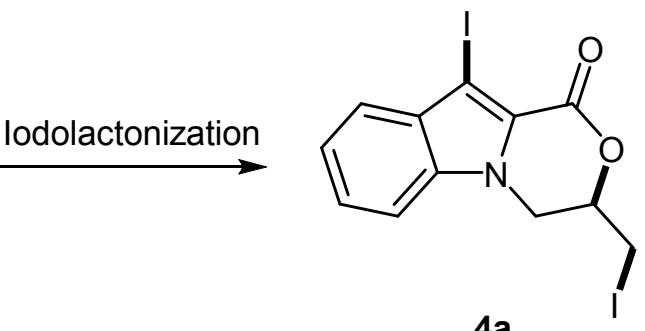

$4 a$

\begin{tabular}{|c|c|c|c|c|c|c|}
\hline Entry & Electrophile (equiv) & $\operatorname{Temp}\left({ }^{\circ} \mathrm{C}\right)$ & Base (equiv) & Solvent (ratio) & Additif (equiv) & Yielda (\%) \\
\hline 1 & $I_{2}(3)$ & 70 & $\mathrm{NaHCO}_{3}(3)$ & $\mathrm{CHCl}_{3} / \mathrm{H}_{2} \mathrm{O}(1 / 3)$ & - & 84 \\
\hline 2 & $\operatorname{NIS}(2.3)$ & -20 & $\mathrm{NaHCO}_{3}(3)$ & $\mathrm{CH}_{2} \mathrm{Cl}_{2}$ & 2,6-lutidine & 81 \\
\hline 3 & $\mathrm{ICl}(3)$ & 70 & $\mathrm{NaHCO}_{3}(3)$ & $\mathrm{CH}_{2} \mathrm{Cl}_{2}$ & - & 54 \\
\hline 4 & NBS (3) & 70 & $\mathrm{NaHCO}_{3}(3)$ & $\mathrm{CH}_{2} \mathrm{Cl}_{2}$ & - & -b \\
\hline 5 & $I_{2}(3)$ & 70 & $\mathrm{~K}_{2} \mathrm{CO}_{3}(3)$ & $\mathrm{CHCl}_{3} / \mathrm{H}_{2} \mathrm{O}(1 / 3)$ & - & 80 \\
\hline 6 & $I_{2}(3)$ & 70 & $\mathrm{Na}_{2} \mathrm{CO}_{3}(3)$ & $\mathrm{CHCl}_{3} / \mathrm{H}_{2} \mathrm{O}(1 / 3)$ & - & 80 \\
\hline 7 & $I_{2}(3)$ & 70 & $\mathrm{KOH}(3)$ & $\mathrm{CHCl}_{3} / \mathrm{H}_{2} \mathrm{O}(1 / 3)$ & - & 80 \\
\hline 8 & $I_{2}(3)$ & 25 & $\mathrm{NaH}(2)$ & $\mathrm{CH}_{2} \mathrm{Cl}_{2}$ & - & 88 \\
\hline 9 & $I_{2}(3)$ & 25 & $\mathrm{NaH}(2)$ & $\mathrm{CH}_{2} \mathrm{Cl}_{2}$ & $\mathrm{AgNO}_{3}(0.5)$ & 99 \\
\hline 10 & $I_{2}(3)$ & 25 & $\mathrm{NaH}(2)$ & $\mathrm{CH}_{2} \mathrm{Cl}_{2}$ & $\mathrm{AgNO}_{3}(1)$ & $96^{c}$ \\
\hline 11 & $I_{2}(3)$ & 25 & $\mathrm{NaH}(2)$ & $\mathrm{CH}_{2} \mathrm{Cl}_{2}$ & $\mathrm{AgNO}_{3}(1.5)$ & 96 \\
\hline
\end{tabular}

a Isolated yields after column chromatography.

b Starting material, no bromolactonization was observed.

c 30 min time of reaction.

Next, we examined the reactivity of the di-iodinated indole $4 \mathbf{a}$ via CuAAC-based MCR in order to obtain the desired triazole compound 6a. Various one-pot multicomponent syntheses of 1,2,3-triazoles starting from organic halides have been reported in the literature. We first examined the reaction of di-iodinated indole $\mathbf{4 a}$ according to a literature procedure for an analogous transformation. ${ }^{[15]}$ In our case, the starting di-iodinated indole $4 \mathbf{a}$ was reacted with sodium azide and phenyl acetylene at $50{ }^{\circ} \mathrm{C}$ in $\mathrm{EtOH} / \mathrm{H}_{2} \mathrm{O}$ for $15 \mathrm{~h}$, in the presence of copper iodide. Under these conditions, no desired product $6 \mathbf{a}$ was formed. Although we tested various conditions by changing the solvents, copper catalysts, base and temperature used for this onepot two-step sequence, no successful combination was found. 


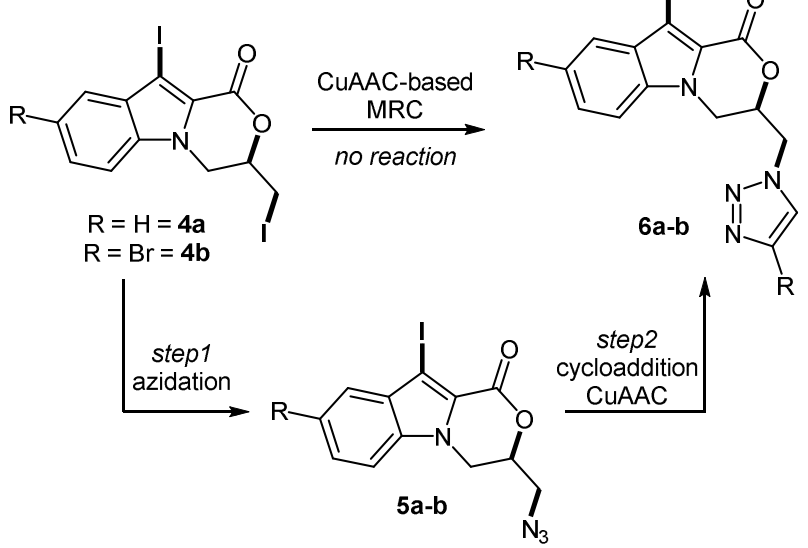

Scheme 2. Synthetic routes towards triazole-bearing oxazinoindolones.

To access the desired compound 6a, a two-step strategy for the click reaction was therefore adopted (Scheme 2). Di-iodinated precursor 4a was subjected to nucleophilic substitution to introduce the azide group under conditions similar to those already employed for related substrates. ${ }^{[16]}$ Preliminary experiments were carried out using sodium azide in $\mathrm{MeOH} / \mathrm{H}_{2} \mathrm{O}$ at room temperature. Only a complex mixture of products was obtained, so different reaction conditions were tested. Initially, we screened the solvent used for the substitution of $\mathbf{4 a}$ to form the azide 5a, and found that the use of aprotic solvents DMF, acetone and MeCN gave the desired product in only low yield (30\%). An increase in the quantity of $\mathrm{NaN}_{3}$ from 3 to 6 equivalents did not improve the yield of the reaction, and in all cases the isolated yield of the desired product $5 \mathbf{a}$ did not exceed $40 \%$. We also found that increasing the temperature from 25 ${ }^{\circ} \mathrm{C}$ to $55{ }^{\circ} \mathrm{C}$ gave only a mixture of products and no desired product $5 \mathbf{a}$ was isolated. However, the use of phase transfer agents as additives proved to be crucial to improve the outcome of the reaction (Scheme 3). ${ }^{[17]}$ We found that the best phase transfer agent was 18 -crown-6 rather than TBAI or TBAF. Further investigations showed that increasing the amount of additive reduced the reaction time but did not give better yields. Significantly, the protocol was also tolerant of the di-iodinated precursor $\mathbf{3 b}$ to furnish the product $\mathbf{4 b}$ in $88 \%$ yield.

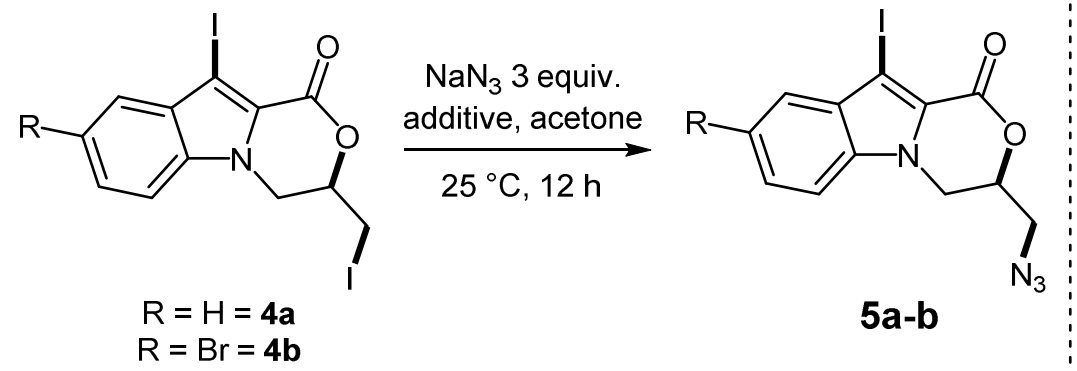

Additive $=18$

crown-6

5 a, $90 \%$

Additive $=$ TBAI

5a, $68 \%$

Additive $=\mathrm{TBAF}$

5a, $68 \%$ 
Scheme 3. Optimization of the reaction between indole-fused oxazinones $\mathbf{4 a - b}$ and sodium azide.

This success in the synthesis of 5a-b led us to investigate cycloaddition (CuAAC) reactions of the azide for building systems bearing a 1,2,3-triazole moiety. Traditional approaches for the synthesis of 1,2,3-triazoles starting from an azide precursor have been reported in the literature. ${ }^{[18]} \mathrm{A}$ first attempt with $\mathrm{CuSO}_{4}, 5 \mathrm{H}_{2} \mathrm{O}$ (10 mol\%), sodium ascorbate $(20 \mathrm{~mol} \%)$ and phenylacetylene (1.5 equiv) in toluene/ $\mathrm{H}_{2} \mathrm{O}$ (3:1) at room temperature provided the corresponding product with a moderate yield (53\%). After testing different solvents, we found that by using chlorinated solvents, such as $\mathrm{CH}_{2} \mathrm{Cl}_{2}$ or $\mathrm{CHCl}_{3}$, the products $\mathbf{6 a - b}$ could be obtained in higher yields ( $89 \%$ and $82 \%$ respectively) (Scheme 4 ).
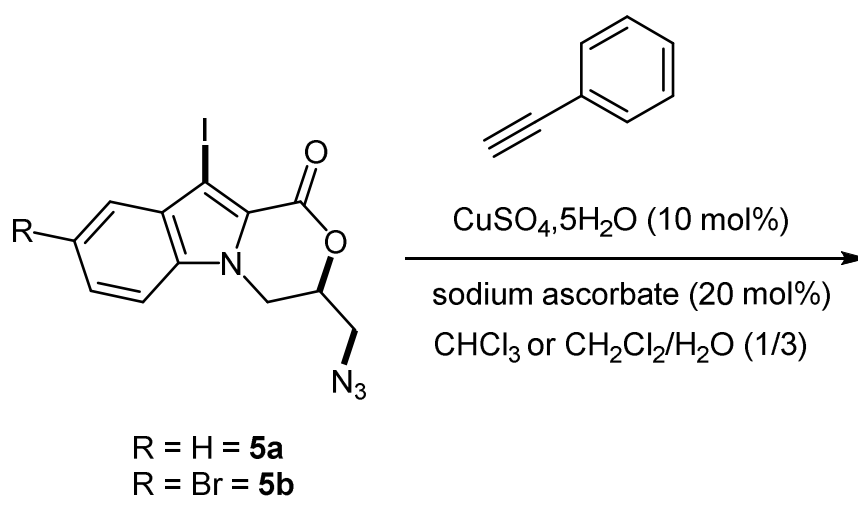

$\mathrm{R}=\mathrm{Br}=\mathbf{5 b}$

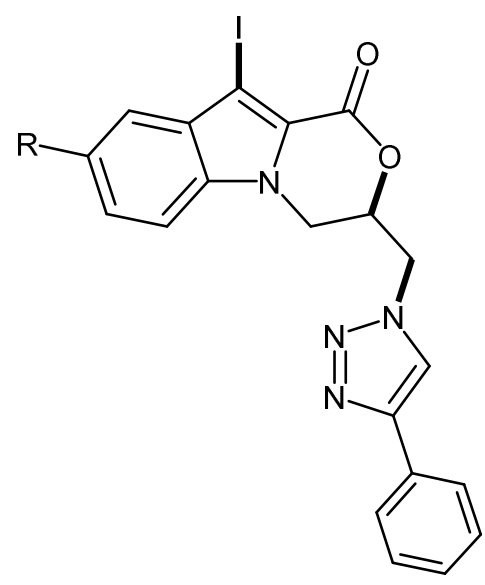

$6 \mathrm{a}=89 \%$

$6 \mathrm{~b}=82 \%$

Scheme 4. 1,3-Dipolar cycloaddition between 5a-b and phenylacetylene.

In a continuation of In keeping with our efforts to examine the reactivity of $\mathbf{5 a}$, we attempted to synthesize 5-iodotriazole 7 through a simple one-pot cycloaddition/iodination reaction. Initially, we tested this reaction under conditions previously defined by our group (Table 2, entry 1). ${ }^{[19]}$ This protocol gave the desired product 7 in 55\% yield and with a 27/73 ratio of $\mathbf{6 a} / 7$, respectively. To increase the selectivity of the reaction, we examined a range of solvents, catalysts, and reaction times. The use of $\mathrm{I}_{2}$ or NBS as an electrophilic trapping reagent did not give better results than with ICl (Table 2, entries 2 and 3). Next, we screened other organic solvents (Table 2, entry 4 and 5). The use of chlorinated solvents, such as $\mathrm{CH}_{2} \mathrm{Cl}_{2}$ or $\mathrm{CHCl}_{3}$, improved the yield of this one pot reaction but always gave a mixture of $\mathbf{7}$ and the monoiodinated compound $\mathbf{6 a}(85: 15)$. The addition of catalysts, such as NaI or LiI was unsuccessfully tested (Table 2, entries 6 and 7). We therefore turned our attention to the reaction duration, and 
it appeared that extended reaction times increased the yield of the side product $6 \mathbf{6}$ (Table 2, entries 8-11). The best result in terms of yield and selectivity was obtained when the reaction time was limited to 48-50 h (Table 2, entries 8 and 9).

Table 2. Optimization of one-pot cycloaddition/iodation reaction.

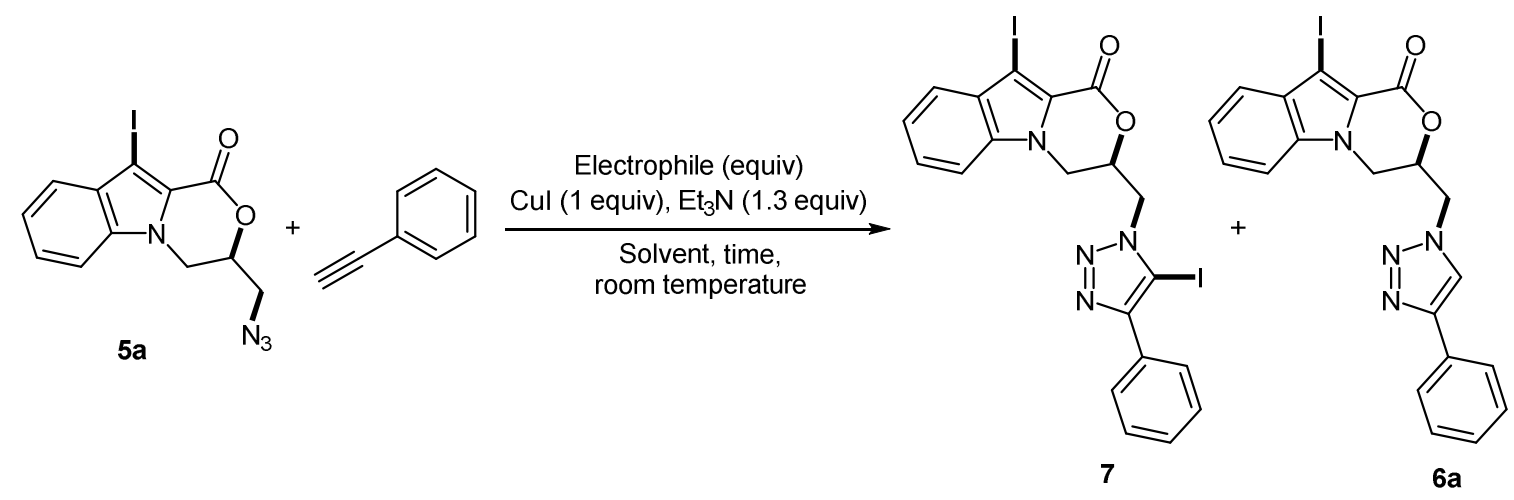

\begin{tabular}{|c|c|c|c|c|c|}
\hline Entry & Electrophile (equiv) & Solvent & Time0 (h) & Ratio $(7 / 6 a)^{a}$ & Yield of $7(\%)^{b}$ \\
\hline 1 & $\mathrm{ICI}(1.2)$ & THF & 60 & $(73 / 27)$ & 55 \\
\hline 2 & NBS (1.2) & THF & 60 & - & -c \\
\hline 3 & $I_{2}(1.2)$ & THF & 60 & $(71 / 29)$ & 46 \\
\hline 4 & $\mathrm{ICl}(1.2)$ & $\mathrm{CHCl}_{3}$ & 60 & $(85 / 15)$ & 74 \\
\hline 5 & $\mathrm{ICl}(1.2)$ & $\mathrm{CH}_{2} \mathrm{Cl}_{2}$ & 60 & $(88 / 12)$ & 70 \\
\hline 6 & $\mathrm{ICl}(1.2))$ & $\mathrm{CHCl}_{3}$ & 60 & $(88 / 12)$ & $72^{d}$ \\
\hline 7 & $\mathrm{ICl}(1.2)$ & $\mathrm{CHCl}_{3}$ & 60 & $(88 / 12)$ & $74^{e}$ \\
\hline 8 & $\mathrm{ICl}(1.2)$ & $\mathrm{CHCl}_{3}$ & 50 & $(90 / 10)$ & 77 \\
\hline 9 & $\mathrm{ICl}(1.2)$ & $\mathrm{CHCl}_{3}$ & 48 & $(93 / 7)$ & 76 \\
\hline 10 & $\mathrm{ICl}(1.2)$ & $\mathrm{CHCl}_{3}$ & 40 & $(95 / 5)$ & 60 \\
\hline 11 & $\mathrm{ICl}(1.2)$ & $\mathrm{CHCl}_{3}$ & 72 & $(66 / 34)$ & 53 \\
\hline
\end{tabular}

a Ratios were measured via ${ }^{1} \mathrm{H}$ NMR.

b Isolated yields.

c Degradation.

${ }^{\mathrm{d}}$ Addition of $20 \mathrm{~mol} \%$ of Lil.

e Addition of 20 mol\% of Nal.

Multicomponent reactions are chemical processes which represent an economically useful way to synthesize a large number of potentially bioactive molecules by combining several reaction steps in a single operation. For example, various MCR syntheses of 1,2,3-triazoles have been published in the past decade starting from organic halides, sodium azide, and terminal alkynes. Our preliminary results showed that 1,2,3-triazoles could be obtained in very good yields only in the presence of 18-crown-6 starting from the corresponding 4a through the classical two-step route. $^{[20]}$ With this knowledge in hand, we re-attempted the one-pot process for the two previously defined steps to prepare the substrate 6a-b from the organic halides 4a-b. Pleasingly, this time the multicomponent reaction worked well in the presence of 18 -crown- 6 , and the 
desired 1,2,3-triazoles 6a-b were obtained in 90 and $88 \%$ yield respectively. Using the optimized conditions, we then focused on exploring the scope of this reaction with various alkynes and sodium azide. The corresponding indole-fused oxazinone-1, 2, 3-triazole scaffolds 6a-l were isolated in good to excellent yields. As shown in Scheme 5, both electronwithdrawing and electron-donating groups can be successfully incorporated in the alkyne component, without substantially altering the one-pot process' efficiency.
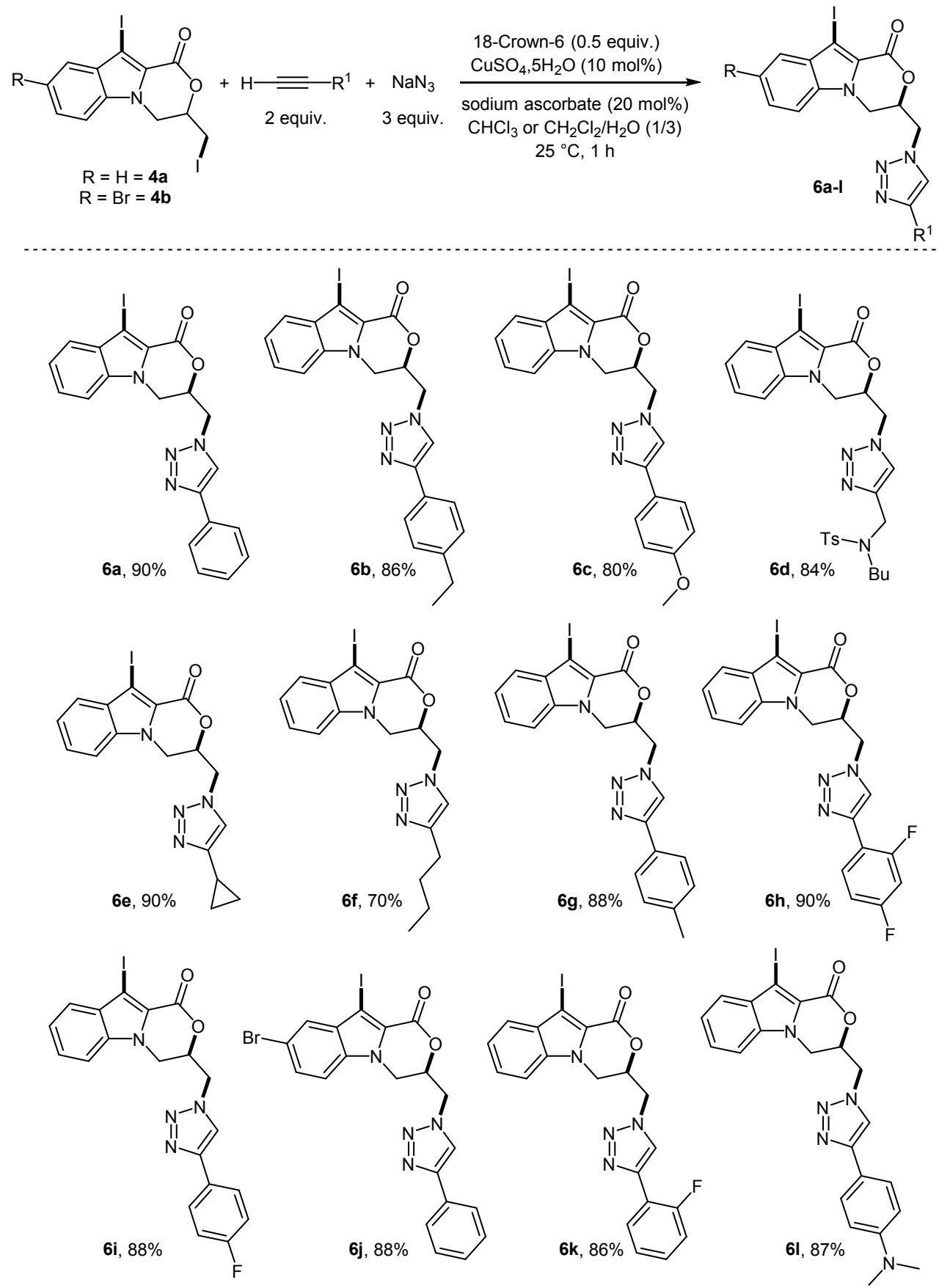

Scheme 5. Synthesis of triazole-bearing oxazinoindolones through a CuAAC one-pot procedure. 
We have also shown that iodo-triazole 7 could efficiently be obtained via a simple one-pot cycloaddition/iodination reaction starting from azido-indole-fused oxazinones. We supposed that indole-fused oxazinone $4 \mathbf{a}$ could be converted into iodotriazole 7 in the presence of 18 crown-6 via a MCR process (Scheme 6). In this context, indole-fused oxazinone 4a, phenylacetylene, sodium azide and $\mathrm{ICl}$ were reacted in the presence of copper iodide, 18-crown6 and $\mathrm{Et}_{3} \mathrm{~N}$ as base. Under these conditions, the desired iodo-triazole 7 was obtained in $76 \%$ yield as a major product but mixed with $5 \%$ of $6 \mathbf{a}$. It was found that 18 -crown- 6 is indispensable for this multicomponent click reaction. This one-pot reaction led to the isolation of the desired iodo-triazole 7 with a better yield than in the two-step sequence (70\%).
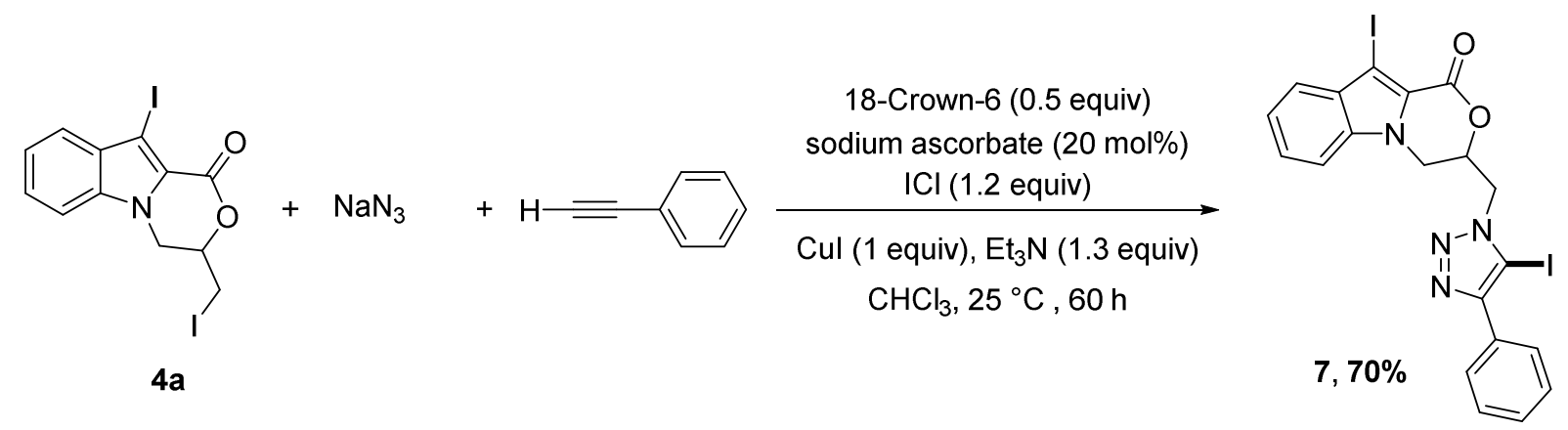

Scheme 6. One-pot azidation/cycloaddition/iodation reaction.

\section{Conclusions}

In summary, we have developed a new protocol to prepare indole-fused oxazinones. We have also demonstrated that these gave access to a novel series of heterocyclic derivatives based on triazole and indole-fused oxazinones, prepared using $\mathrm{CuAAC}$ based multicomponent reactions. Further investigations concerning the resulting products 6a-i are ongoing in our laboratory, and an evaluation of their biological activity is underway at the Lilly platform.

\section{Experimental}

General procedure for the synthesis of ethyl 1-Allyl-5-bromo-1H-indole-2-carboylate (2b)

In a two-necked round bottom flask, $\mathrm{NaH} 60 \%$ (44 mg, $1.1 \mathrm{mmol}, 1.1$ equiv.) was dissolved in DMF (6 mL). Compound $\mathbf{1 b}\left(1 \mathrm{mmol}, 1\right.$ equiv.) in DMF (3 mL) was added dropwise at $0{ }^{\circ} \mathrm{C}$ under argon. The mixture was stirred for $30 \mathrm{~min}$ at room temperature. A solution of allyl 
bromide (145.2 mg, $1.2 \mathrm{mmol}, 1.2$ equiv.) in DMF (3 mL) was added dropwise at $0{ }^{\circ} \mathrm{C}$. After $4 \mathrm{~h}$ of stirring at room temperature, the mixture was hydrolyzed by aqueous $\mathrm{NH}_{4} \mathrm{Cl}(20 \mathrm{~mL})$, extracted by diethyl ether $(6 \times 10 \mathrm{~mL})$, and the organic phases were washed with brine $(3 \times 10$ $\mathrm{mL}$ ), dried over $\mathrm{MgSO}_{4}$ and concentrated under vacuum.

\section{General procedure for the synthesis of indole-2-carboxylic acids 3}

In a round bottom flask, $\mathrm{NaOH} \mathrm{12 \%} \mathrm{(240} \mathrm{mg,} 6 \mathrm{mmol}, 3$ equiv.) was slowly added to a solution of indole ester 2a-b ( $2 \mathrm{mmol}, 1$ equiv.) in ethanol $(6 \mathrm{~mL})$. The mixture was stirred at $45^{\circ} \mathrm{C}$ for $3 \mathrm{~h}$, cooled to $0{ }^{\circ} \mathrm{C}$ and acidified with $\mathrm{HCl}(1 \mathrm{M})$ to obtain $\mathrm{pH}=1$. The resulting precipitate was filtered and washed with hexane.

\section{General procedure for the synthesis of iodoindole-fused oxazinones 4}

In a round bottom flask containing carboxylic acid $3(1.11 \mathrm{mmol})$ and $25 \mathrm{~mL}$ of $\mathrm{CH}_{2} \mathrm{Cl}_{2}$ were added sodium hydride $(88 \mathrm{mg}, 2.22 \mathrm{mmol})$, iodine $(845 \mathrm{mg}, 3.33 \mathrm{mmol}$ ) and silver nitrate (94 $\mathrm{mg}, 0.55 \mathrm{mmol})$. The mixture was stirred overnight at room temperature. The medium was hydrolyzed by saturated solution of $\mathrm{Na}_{2} \mathrm{~S}_{2} \mathrm{O}_{3}(30 \mathrm{~mL})$ then extracted by dichloromethane $(3 \times$ $25 \mathrm{~mL})$. The organic phase was washed with $\mathrm{NaCl}(3 \times 10 \mathrm{~mL})$, dried over $\mathrm{MgSO}_{4}$ and concentrated under vacuum to give the products $4 \mathbf{a}-\mathbf{b}$. Spectroscopic data of known compound 4a are identical to those reported previously. ${ }^{[14]}$

\section{General procedure for the synthesis of azides 5}

A mixture of the appropriate 4a-b $(0.76 \mathrm{mmol})$, sodium azide (148 mg, $2.28 \mathrm{mmol})$, 18-crown$6(100 \mathrm{mg}, 0.38 \mathrm{mmol})$ and acetone $(20 \mathrm{~mL})$ was stirred at room temperature until completion of the reaction (TLC). The solvents were evaporated under reduced pressure, and the mixture was then poured into water, extracted with $\mathrm{CH}_{2} \mathrm{Cl}_{2}(3 \times 40 \mathrm{~mL})$, dried $\left(\mathrm{MgSO}_{4}\right)$, and concentrated in vacuum. The crude product was purified by silica gel chromatography using $\mathrm{PE} /$ EtOAc (1:4) mixture as eluent.

General procedure for the synthesis of triazoles 6

\section{Starting from Azide 5:}


Finely powdered $\mathrm{CuSO}_{4}, 5 \mathrm{H}_{2} \mathrm{O}(10 \mathrm{~mol} \%)$ and sodium ascorbate $(20 \mathrm{~mol} \%)$ were slowly added to a stirred solution of $5(0.8 \mathrm{mmol})$ and appropriate terminal alkyne $(1.2 \mathrm{mmol})$ in $\mathrm{H}_{2} \mathrm{O} / \mathrm{CHCl}_{3}$ $(3: 1=22.5 \mathrm{~mL} / 7.5 \mathrm{~mL})$ at $0-10{ }^{\circ} \mathrm{C}$. The mixture was then warmed to room temperature and stirred until completion (TLC). The mixture was filtered, concentrated and diluted with water $(30 \mathrm{~mL})$. The aqueous layer was extracted with $\mathrm{CHCl}_{3}(3 \times 20 \mathrm{~mL})$. The combined organic layers were washed with $\mathrm{H}_{2} \mathrm{O}$ and then with brine, dried over $\mathrm{MgSO}_{4}$ and concentrated in vacuum. The crude products were purified by flash chromatography on silica gel $(\mathrm{EtOAc} / \mathrm{PE}=$ 4:1) to afford the pure triazoles $\mathbf{6 a}$ and $\mathbf{6 c - 1}$.

\section{Starting from bis-iodine 4:}

Sodium azide (148 mg, $2.28 \mathrm{mmol})$ and 18-crown-6 $(100 \mathrm{mg}, 0.38 \mathrm{mmol})$ were added to a solution of compound $4(0.76 \mathrm{mmol})$ in $\mathrm{H}_{2} \mathrm{O} / \mathrm{CHCl}_{3}(3: 1=22.5 \mathrm{~mL} / 7.5 \mathrm{~mL})$, and the suspension was stirred for $30 \mathrm{~min}$. The mixture was then degassed at $0^{\circ} \mathrm{C}$ and terminal alkyne $(4.0 \mathrm{mmol})$, sodium ascorbate $(641 \mathrm{mg}, 4.0 \mathrm{mmol})$ and $\mathrm{CuSO}_{4}, 5 \mathrm{H}_{2} \mathrm{O}(76 \mathrm{mg}, 0.4 \mathrm{mmol})$ were successively added. The mixture was stirred overnight. The reaction was quenched by the addition of an aqueous saturated $\mathrm{NH}_{4} \mathrm{Cl}$ solution. After being stirred for further $15 \mathrm{~min}$, the mixture was filtered through a Celite pad. The aqueous phase was extracted with EtOAc (3 x $20 \mathrm{~mL})$ and the combined organic layers were washed with brine, dried over $\mathrm{MgSO}_{4}$ and concentrated under reduced pressure. The crude material was then purified by flash chromatography on silica gel $(\mathrm{EtOAc} / \mathrm{PE}=4: 1)$ giving compounds $\mathbf{6} \mathbf{a}$ and $\mathbf{6 b}$.

\section{General procedure for the synthesis of triazole 7}

\section{Starting from Azide 5:}

A mixture of azide 5a $(1 \mathrm{mmol})$, terminal alkyne $(1.3 \mathrm{mmol}), \mathrm{Et}_{3} \mathrm{~N}(1.2 \mathrm{mmol}), \mathrm{CHCl}_{3}(100$ $\mathrm{mL}), \mathrm{ICl}(195 \mathrm{mg}, 1.2 \mathrm{mmol})$, and CuI (190 mg, $1 \mathrm{mmol})$ was stirred at room temperature under an argon atmosphere for $48 \mathrm{~h}$. The solvent was removed by distillation under reduced pressure and the crude residue was purified by flash chromatography over silica gel $\left(\mathrm{CHCl}_{3} / \mathrm{MeOH}=\right.$ $88: 12$ ) to afford the pure desired triazole product 7 .

\section{Starting from bis-iodine 4:}

Compound 4a-b $(0.76 \mathrm{mmol})$ was dissolved in $\mathrm{CHCl}_{3}(20 \mathrm{~mL})$. Sodium azide (148 mg, 2.28 $\mathrm{mmol})$ and 18 -crown-6 (100 $\mathrm{mg}, 0.38 \mathrm{mmol})$ were then added to the solution and the suspension 
was stirred for $30 \mathrm{~min}$. The mixture was then degassed at $0{ }^{\circ} \mathrm{C}$ and terminal alkyne (4.0 mmol), $\mathrm{Et}_{3} \mathrm{~N}(125 \mu \mathrm{L}, 0.92 \mathrm{mmol}), \mathrm{CuI}(145 \mathrm{mg}, 0.76 \mathrm{mmol})$ and $\mathrm{ICl}(148 \mathrm{mg}, 0.91 \mathrm{mmol})$ were successively added. The mixture was stirred at room temperature under an argon atmosphere for $60 \mathrm{~h}$. The reaction mixture was quenched by the addition of an aqueous saturated $\mathrm{NH}_{4} \mathrm{Cl}$ solution and stirred for further $15 \mathrm{~min}$. The mixture was filtered through a pad of Celite. The aqueous phase was extracted with EtOAc $(3 \times 20 \mathrm{~mL})$ and the combined organic layers were washed with brine, dried over $\mathrm{Na}_{2} \mathrm{SO}_{4}$ and concentrated under reduced pressure. The crude product was then purified by flash chromatography on silica gel $(\mathrm{EtOAc} / \mathrm{PE}=4: 1)$.

\section{Notes}

The authors declare no competing financial interest.

\section{ORCID}

Jérôme Thibonnet ID http://orcid.org/0000-0003-3817-210X

\section{References}

[1] (a) Verpoorte, R. Antimicrobially Active Alkaloids. Alkaloids 1998, 397-433. (b) McKay, M. J.; Carroll, A. R.; Quinn, R. J.; Hooper, J. N. A. 1,2-Bis(1H-indol-3-yl)ethane-1,2-dione, an Indole Alkaloid from the Marine Sponge Smenospongia sp. J. Nat. Prod. 2002, 65, 595597. doi:10.1021/np010347v

[2] Kleinwachter, P.; Schlegel, B.; Groth, I.; Hartl, A.; Grafe, U. New Inhibitors of $3 \alpha-$ Hydroxysteroid Dehydrogenase, 0231A and 0231B from Streptomyces sp. HKI 0231. J. Antibiotics 2001, 54, 510-512. doi:10.7164/antibiotics.54.510

[3] Fernández-Pérez, F.; Almagro, L.; Pedreño, M.A.; GómezRos, L.V. Synergistic and cytotoxic action of indole alkaloids produced from elicited cell cultures of Catharanthusroseus. Pharm. Biol. 2013, 51, 304-310. doi:10.3109/13880209.2012.722646 
[4] Kaushik, N. K.; Kaushik, N.; Attri, P.; Kumar, N.; Kim, C. H.; Verma, A. K.; Choi, E. H. Biomedical importance of indoles. Molecules 2013, 18, 6620-6662. doi:10.3390/molecules 18066620

[5] Rajan, S.; Puri, S.; Kumar, D.; Babu, M. H.; Shankar, K.; Varshney, S.; Srivastava, A.; Gupta, A.; Reddy, M. S.; Gaikad, A. N. Novel indole and triazole based hybrid molecules exhibit potent anti-adipogenic and antidyslipidemic activity by activating $\mathrm{Wnt} 3 \mathrm{a} / \beta$-catenin pathway. Eur. J. Med. Chem. 2018, 143, 1345-1360. doi:10.1016/j.ejmech.2017.10.034

[6] Minvielle, M. J.; Bunders, C. A.; Melander, C. Indole-triazoleconjugates are selective inhibitors and inducers of bacterial biofilms. Med. Chem. Commun. 2013, 4, 916-919. doi:10.1039/C3MD00064H

[7] Pawar, K.; Yadav, A.; Prasher, P.; Mishra, S.; Singh, B.; Singh, P.; Komath, S. S. Identification of an indole-triazole-amino acid conjugate as a highly effective antifungal agent. Med. Chem. Commun. 2015, 6, 1352-1359. doi:10.1039/C5MD00156K

[8] Reddy, B. S.; Reddy, B. S.; Rao, C.; Subha, M. C. S. Synthesis of some new 1,2,3-triazole derivatives of indole with potential antimicrobial activity. World J. Pharm. Pharm. Sci. 2015, 4, 1084-1090.

[9] Naveen, P.; Nikhila, G.; Udayakumar, D.; Pulla, V. K.; Perumal, Y.; Dharmarajan, S. Synthesis of novel 5-[(1,2,3-triazol-4-yl)methyl]1-1methyl-3Hpyridazino[4,5-b]indol-4one by click reaction and exploration anticancer activity. Med. Chem. Res. 2016, 25, 135148. doi:10.1007/s00044-015-1473-y

[10]D’Ambra, T. E.; Estep, K. G.; Bell, M. R.; Eissenstat, M. A.; Josef, K. A.; Ward, S. J.; Haycock, D. A.; Baizman, E. R.; Casiano, F. M.; Beglin, N. C.; Chippari, S. M.; Grego, J. D.; Kullnig, R. K.; Daley, G. T. Conformationally restrained analogs of pravadoline: nanomolar potent, enantioselective, (aminoalkyl)indole agonists of the cannabinoid receptor. J. Med. Chem. 1992, 35, 124-135. doi: 10.1021/jm00079a016.

[11]Ayral-Kaloustian, S.; Zhang, N.; Venkatesan, A. M.; Mansour, T. S.; Nguyen, T. H.; Anderson, J. T. U.S. Pat. Appl. Publ. 2009, US 20090192147 A1 20090730.

[12](a) Radwan, M. A. A.; Ragab, E. A.; Sabry, N. M.; El-Shenawy, S. M. Synthesis and biological evaluation of new 3-substituted indole derivatives as potential anti-inflammatory and analgesic agents. Bioorg. Med. Chem. 2007, 15, 3832-3841. doi: 
10.1016/j.bmc.2007.03.024. (b) Sharma, V.; Kumar, P.; Pathak, D. Biological importance of the indole nucleus in recent years: A comprehensive review. J. Heterocycl. Chem. 2010, 47, 491-502. doi:10.1002/jhet.349

[13]Inaba, S.; Ishizumi, K.; Akatsu, M.; Kume, R.; Mori, K.; Yamamoto, H. Jpn. Tokkyo Koho, 1974, JP 49004238 B 19740131.

[14](a) Putey, A.; Fournet, G.; Joseph, B. General and Easy Access to 11-Substituted 4Hydroxy-2,3,4,5-tetrahydro[1,4]diazepino[1,2-a]indol-1-one Derivatives. Synlett 2006, 2755-2758. doi: 10.1055/s-2006-950249. (b) Putey, A.; Popowycz, F.; Joseph, B. A NonClassical Route to 2,3-Diiodoindoles from Indole-2-carboxylic Acids. Synlett 2007, 419422. doi:10.1055/s-2007-967953

[15](a) Kumar, D.; Patel, G.; Reddy, V. B. Greener and Expeditious Synthesis of 1,4Disubstituted 1,2,3-Triazoles from Terminal Acetylenes and in situ Generated $\alpha$-Azido Ketones. Synlett 2009, 399-402. doi:10.1055/s-0028-1087556. (b) Alonso, F.; Moglie, Y.; Radivoy, G.; Yus, M. Copper-Catalysed Multicomponent Click Synthesis of 5-Alkynyl 1,2,3-Triazoles under Ambient Conditions. Synlett 2012, 2179-2182. doi:10.1055/s-00311290445. (c) Mukherjee, N.; Ahammed, S.; Bhadra, S.; Ranu, B. C. Solvent-free one-pot synthesis of 1,2,3-triazole derivatives by the 'Click' reaction of alkyl halides or aryl boronic acids, sodium azide and terminal alkynes over a $\mathrm{Cu} / \mathrm{Al}_{2} \mathrm{O}_{3}$ surface under ball-milling. Green Chem. 2013, 15, 389-397. doi:10.1039/C2GC36521A. (d) Feldman, A. K.; Colasson, B.; Fokin, V. V. One-Pot Synthesis of 1,4-Disubstituted 1,2,3-Triazoles from In Situ Generated Azides. Org. Lett. 2004, 6, 3897-3899. doi:10.1021/o1048859z. (e) Safa, K. D.; Mousazadeh, H. Synthesis of novel 1,4-disubstituted 1,2,3-triazoles bearing organosiliconsulfur groups via the click reaction sonocatalyzed by $\mathrm{LaCu}_{\mathrm{x}} \mathrm{Mn}_{1-\mathrm{x}} \mathrm{O}_{3}$. Synth. Commun. 2016, 46, 1595-1604. doi:10.1080/00397911.2016.1217339. (f) Guo, S.; Zhou, Y.; Dai, B.; Huo, C.; Liu, C.; Zhao, Y. CuI/Et 2 NH-Catalyzed One-Pot Highly Efficient Synthesis of 1,4Disubstituted 1,2,3-Triazoles in Green Solvent Glycerol. Synthesis 2018, 2191-2199. doi:10.1055/s-0036-1591557.

[16](a) Feula, A.; Dhillon, S. S.; Byravan, R.; Sangha, M.; Ebanks, R.; Salih, M. A. H.; Spencer, N.; Male, L.; Magyary, I.; Deng, W.-P.; Müller, F.; Fossey, J. S. Synthesis of azetidines and pyrrolidines via iodocyclisation of homoallyl amines and exploration of activity in a zebrafish embryo assay. Org. Biomol. Chem. 2013, 11, 5083-5093. doi:10.1039/C3OB41007B. (b) Yi, M.; Gu, P.; Kang, X.-Y.; Sun, J.; Li, R.; Li, X.-Q. Total 
synthesis of ( \pm )-antofine. Tetrahedron Lett. 2014, 55, 105-107. doi:10.1016/j.tetlet.2013.10.124.

[17]Patonay, T.; Juhász-Tóth, E.; Bényei, A. Base-Induced Coupling of $\alpha$-Azido Ketones with Aldehydes-An Easy and Efficient Route to Trifunctionalized Synthons 2-Azido-3-hydroxy Ketones, 2-Acylaziridines, and 2-Acylspiroaziridines. A. Eur. J. Org. Chem. 2002, 285295. doi:10.1002/1099-0690(20021)2002:2<285::AID-EJOC285>3.0.CO;2-J.

[18](a) Meldal, M.; Tornøe, C. W. Chem. Rev. 2008, 108, 2952-3015. doi:10.1021/cr0783479. (b) Hein, J. E.; Fokin, V. V. Chem. Soc. Rev. 2010, 39, 1302-1315. doi:10.1039/B904091A. (c) Hassan, S.; Müller, T. J. J. Multicomponent Syntheses based upon Copper-Catalyzed Alkyne-Azide Cycloaddition. Adv. Synth. Catal. 2015, 357, 617-666. doi:10.1002/adsc.201400904. (d) Baltus, C. B.; Jorda, R.; Marot, C.; Berk, K.; Bazgier, V.; Krystof, V.; Prié, G.; Viaud-Massuard, M. C. Synthesis, biological evaluation and molecular modeling of a novel series of 7-azaindole based tri-heterocyclic compounds as potent CDK2/Cyclin E inhibitors. Eur. J. Org. Chem. 2016, 701-719. doi:10.1016/j.ejmech.2015.12.023. (e) Camp, C.; Dorbes, S.; Picard, C.; Benoist, E. Efficient and tunable synthesis of new polydentate bifunctional chelating agents using click chemistry. Tetrahedron Lett. 2008, 49, 1979-1983. doi:10.1016/j.tetlet.2008.01.086. (f) Mishra, K. B.; Tiwari, V. K. Click Chemistry Inspired Synthesis of Morpholine-Fused Triazoles. J. Org. Chem. 2014, 79, 5752-5762. doi:10.1021/jo500890w. (g) Shamim, A.; Vasconcelos, S. N. S.; De Oliveira, I. M.; Reis, J. S.; Pimenta, D. C.; Zukerman-Schpector, J.; Stefani, H. A. Synthesis of Glycosyl Azides and Their Applications Using CuAAC Click Chemistry to Generate Bis- and Tris(triazolyl)glycosyl Derivatives. Synthesis 2017, 51835196. doi:10.1055/s-0036-1589090. (h) Martinelli, M.; Milcent, T.; Ongeri, S.; Crousse, B. Synthesis of new triazole-based trifluoromethyl scaffolds. Beilstein J. Org. Chem. 2008, 4 (19). doi:10.3762/bjoc.4.19.

[19]Carcenac, Y.; David-Quillot, F.; Abarbri, M.; Duchêne, A.; Thibonnet, J. PalladiumCatalyzed Cross-Coupling of 1,4-Disubstituted 5-Iodo-1,2,3-triazoles with Organotin Reagents. Synthesis 2013, 633-638. doi:10.1055/s-0032-1318112.

[20]Mayooufi, A.; Romdhani-Younes, M.; Thibonnet, J. SynOpen 2018, 2, 298-305. doi:10.1055/s-0037-1610399. 